\title{
Balanced Scorecard and Private Universities' Performance in South-Western, Nigeria
}

\author{
OLASUNKANMI Musibau Lanre \\ Department of Accounting, College of Social and Management Science \\ Afe Babalola University, Ado-Ekiti, Ekiti State, Nigeria \\ ASAOLU Taiwo Olufemi, PhD \\ Professor of Accounting, Department of Management and Accounting \\ Obafemi Awolowo University, Ile-Ife, Osun State
}

\begin{abstract}
Performance evaluation is a means of measuring performance. The purpose of measuring performance is not to indicate only where things are not going according to plan (i.e. corporate strategies) but also to identify why things are going well (operational concerns) so that steps can be taken to build on success. This study was carried out to examine the suitability and capability of private universities in south-western, Nigeria in the evaluation of performance. It also revealed the effects of Balanced Scorecard (BSC) on performance evaluation of private universities. The study adopted a descriptive survey design with primary sources of data and 300 structured questionnaires were administered as well as a personal interview conducted. The population of the study is 61 private universities in the country. The study only focused on 3 private universities on the basis of religion faithbased (Christian-faith, Islamic-faith and others). Data collected from the questionnaires were analysed using simple percentage and chi-square. The study revealed that the Balance Scorecard (BSC) is suitable and private universities have the capacity to implement the system for performance evaluation. It was recommended that University administrators need to communicate the BSC process, outcomes, and application with greater clarity to all employees both academic and non-academic staff and that the Nigeria University Commission (NUC) as the major regulatory bodies and others should encourage private universities to implement the BSC for performance evaluation of both the students (customer perspective) and staff (internal process perspective
\end{abstract}

Keywords: Balanced scorecard (BSC), Financial performance, Performance; Perspective; Private Universities

DOI: $10.7176 /$ RJFA/10-8-02

Publication date: April $30^{\text {th }} 2019$

\subsection{INTRODUCTION}

One of the major challenges facing organizations in measuring performance is difficulty on how to equate entity's operational concerns with corporate strategic priorities. According to Armstrong (2001), Performance evaluation is a means of measuring performance. Armstrong who is a major author and scholar in the field of Human Resources Management explained that the purpose of measuring performance is not to indicate only where things are not going according to plan (i.e. corporate strategies) but also to identify why things are going well (operational concerns) so that steps can be taken to build on success. Going by his (Armstrong) perspective to what performance evaluation or measurement indicate, it can be deduced that as competitors in market or business environment increases day by day, an entity or business organization need to measure its performance for two major reasons; Firstly, to assess how business achieved its set objectives (e.g. profit maximization or cost minimization) and build on the strategies put in place for the success. Secondly, to assess what contributes to business failure for not achieving its set objectives and design ways of improving it in future.

Globally, the goal of performance evaluation is to access and summarize past performance, and develop future work, performance goals and expectations. It is a process of systematically evaluating performance and providing feedback on which performance adjustments can be made. There exist different tools which have been adopted by different sectors within the private and public sectors to measure organizational performance. The tools which include ratio analysis; Strength, Weakness, Opportunity and Threat (SWOT) analysis; benchmarking; and business valuation to mention a few are used in the determination of organizational strengths and weaknesses. This will enables the organization to known whether its set objectives have been achieved but if not, after compare with competitors, other means will be designed to meet up or re-strategize. The evaluation can be in terms of financial indicators such as profitability level and liquidity level best assessed through financial ratio analysis. Non-financial indicators such as products or services quality, customers, suppliers and employees are not left out in assessing performance. They are best assessed through Strength, Weakness, Opportunity and Threat (SWOT) analysis and other tools.

All aforementioned performance evaluation tools have been effectively recognized up to early 90 s when another tool called Balanced Scorecard (BSC) was introduced and developed as a performance measurement concept by two scholars of Harvard Business School Robert S. Kaplan and David P. Norton in 1992. The Balanced 
Scorecards which was designed to take care of both financial and non-financial performance indicators has gained ground in the developed countries to evaluate performance of organizations both in the private and public sectors. For examples the users of the BSC model include in the United States government, Intel, Apple; and in the United Kingdom BP Chemicals etc. The BSC was typically applied in business disciplines and in the strategic management area for industries (Lovaglio, 2011). However, BSC can be also proposed in government agencies, universities, and non-profit organizations as suggested by Pietrzak (2014).

In developing nations such as our country Nigeria, application and implementation of the Balanced Scorecard as a tool for performance evaluation has started gaining awareness in some sectors while the concept is new to some. In the educational sector of the country, performance has always been measured based on their profitability level, increase in the number of enrolled students, numbers of first class students in a session, number of professors in the academic section of the institution and many more.

The rapid increase in Nigeria population contributes to high rate of private participation in educational sector of the country especially in tertiary education (universities to be precise). This participation increases condition of competition in the sector every year where strong focus on performance measurement is required. Many literatures had been reviewed on performance measurement and appraisal together with tools used such as ratio analysis etc. It was discovered that major performance measurement tools in organizations have been the implementation of ratio analysis; Strength, Weakness, Opportunity and Threat (SWOT) analysis; value chain and so on. Implementation and suitability of Balanced Scorecard (BSC) technique as a performance management tool in private universities in Nigeria have not been examined (Amponsah \& Onuoha, 2013)

It was gathered that some companies in the banking, telecommunication, and manufacturing sectors have implemented Balanced Scorecards to evaluate their performances in the developed countries like United State of America, United Kingdom, Canada, Singapore, etc. The findings from work of some researchers such as Abdalkrim (2014); Ibrahim and Murtala (2015) revealed that the stated industries or sectors have the capacities (financial, human resources etc.) to implement BSC unlike others like educational sector (especially private universities) in the developing countries without any other sources of finance (such as subvention, grants, etc.) other than school fees.

However, with the advent of high rate of competitions in Nigeria educational sector, the latest techniques (Balanced Scorecard) to assess performance need to be implemented to understand strategy which will provide balance information about financial and non-financial factors from all possible contributing areas in order to achieve total quality through regular improvement of its performance. This research work seek to address specifically the suitability and capacity to implement Balanced Scorecards by private universities in South Western Nigeria for performance evaluation.

\subsection{LITERATURE REVIEW}

\subsection{Conceptual Framework of Balanced Scorecard}

The concept of the Balanced Scorecard (BSC) was developed in the early 1990s as a performance measurement concept by two scholars of Harvard Business School Robert S. Kaplan and David P. Norton. It is a new approach to performance measurement due to problems of short-termism and past orientation in management accounting (Kaplan \& Norton, 1992). BSC takes into account non-financial issues such knowledge, creativity, customer satisfaction; error-free business processes etc. as the indicator of long-term performance of the organization which some other performance measurement tools have not considered. The BSC's is characterized by four perspectives which are financial perspectives, customer perspectives, internal business process perspectives and learning and growth perspectives (Kaplan \& Norton, 2001). Here, the BSC is used to communicate and coordinate the translation of the business strategy (Kaplan \& Norton, 2001): the gap between strategic and operative planning can be bridged and the long term achievement of the strategic objectives guaranteed by means of a consistent application and formulation of a previously defined business strategy in the four perspectives of the BSC (Kaplan \& Norton, 2001). Unconventionally, BSC capitalizes on both non-financial factors as leading indicators whereas financial factors as lagging indicators. The cause and effect relationship adds new dimension to measurement system.

Balanced Scorecard has different definitions from the internet using search engines. These definitions include the following; "A model of business performance evaluation that balances measures of financial performance, internal operations, innovation and learning, and customer satisfaction". "The balanced scorecard is a strategic management system based upon measuring key performance indicators across all aspects and areas of an enterprise: financial; customer; internal process; and learning and growth." "The balanced scorecard is a strategic management and measurement system that links strategic objectives to a comprehensive range of key performance indicators, to provide a balanced view." On the other hands, Kaplan and Norton (1996) wrote that "the Balanced Scorecard translates an organization's mission and strategy into a comprehensive set of performance measures and provides the framework for strategic measurement and management". Kaplan and Norton relate the usefulness of the balanced scorecard to the needs of a pilot steering an aircraft as: "Think of the balanced scorecard as the dials 
and indicators in an airplane cockpit. For the complex task of navigating and flying an airplane, pilots need detailed information about many aspects of the flight. They need information about fuel, air speed, altitude, bearing, destination and other indicators that summarize the current and predicted environment. Reliance on one instrument can be fatal. Similarly, the complexity of managing an organization today requires that managers be able to view performance in several areas simultaneously" (Kaplan \& Norton, 1992).

The BSC framework is a tool that reveals the cause and effect scenarios in the adopted strategic management structure in an organization in respect of the four perspectives of BSC (Kaplan \& Norton, 2001): financial, customer, internal process and learning and growth.

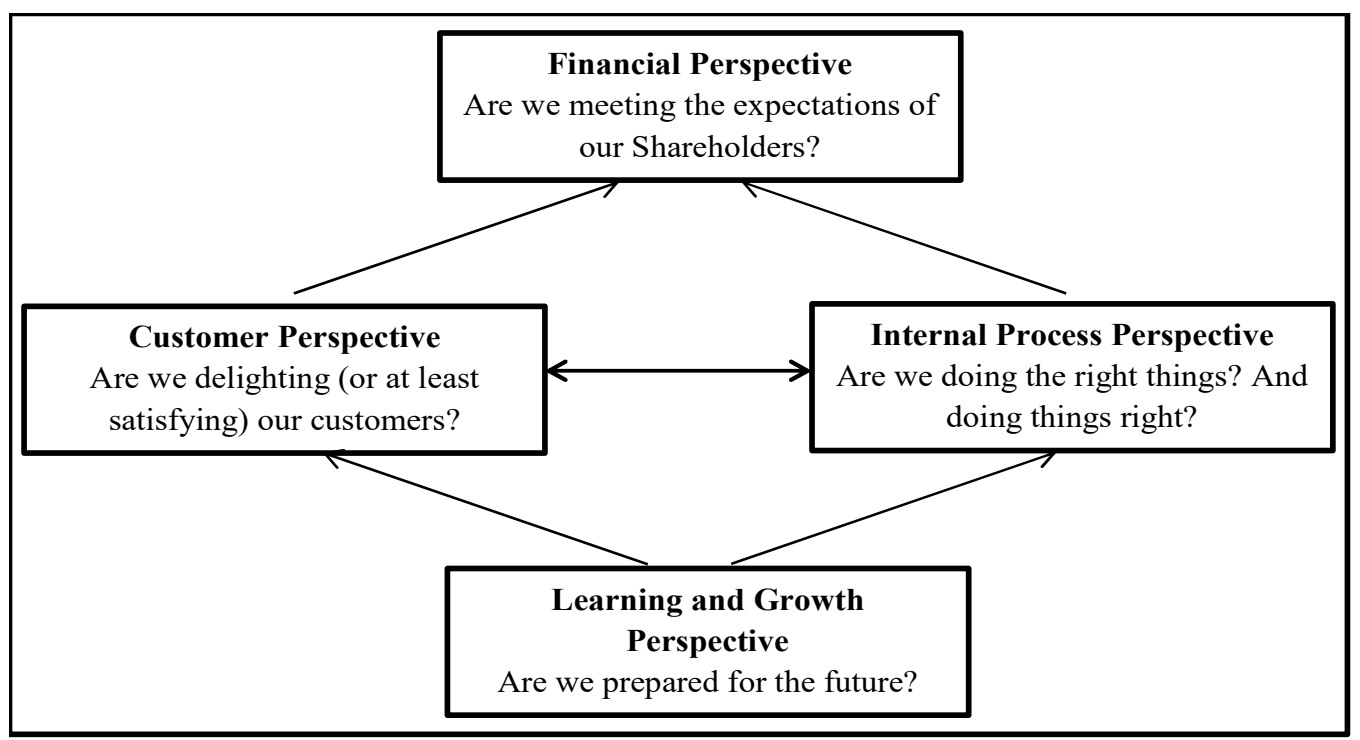

Fig. 2.1 Component of Balanced Scorecard Model

Source: Kaplan and Norton, (1996)

The BSC approach offers a guide for what should be measured to reach the balance of the implications in all functional areas, resulting from the strategic goal (Punniyamoorthy \& Murali, 2008). It is a general and flexible approach to performance measurement and can be adapted to work in companies (including private universities), public sector, and nonprofit enterprises. The BSC measures organizational performance across four different but linked perspectives that are derived from the organization's vision, strategy, and objectives (Atkison, Kaplan \& Young, 2007).

The four measurement perspectives in the BSC, (shown in figure 1 above), are:

i Financial Perspective - How will we look to our stake holders?

ii Customer perspective - How must we look to our customers?

iii Internal processes Perspective - What internal processes must we excel at?

iv Learning and growth Perspective - How can the organization learn and improve?

\subsubsection{Balanced Scorecard and Plan Implementation}

Kaplan and Norton (1992) stated that the objective of the balanced scorecard was to create a system, which could measure the performance of an organization and to improve any back lags that occur. The popularity of the balanced scorecard increased over time due to its logical process and methods. Hence, it became a management strategy, which could be used across various functions within an organization. The balanced scorecard helped the management to understand its objectives and roles in the bigger picture. It also helps management team to measure the performance in terms of quantity. The balanced scorecard also plays a vital role when it comes to communication of strategic objectives. One of the main reasons for many organizations to be unsuccessful is that they fail to understand and adhere to the objectives that have been set for the organization (Lawrie, 2002).

In his work Njeri (2014) he wrote that the balanced scorecard provides a solution for this by breaking down objectives and making it easier for management and employees to understand. Planning, setting targets and aligning strategy are two of the key areas where the balanced scorecard can contribute. Targets are set out for each of the four perspectives in terms of long-term objectives. However, these targets are mostly achievable even in the short run. Measures are taken in align with achieving the targets. Strategic feedback and learning is the next area, where the balanced scorecard plays a role. In strategic feedback and learning, the management gets up-to-date reviews regarding the success of the plan and the performance of the strategy. The balance score card is necessary to; increases the focus on the business strategy and its outcomes, leads to improvised organizational performance 
through measurements and align the workforce to meet the organization's strategy on a day-to-day basis. It is necessary because it targets the key determinants or drivers of future performance, improves the level of communication in relation to the organization's strategy and vision and helps to prioritize projects according to the timeframe and other priority factors (Hanson \& Towle, 2000).

According to Kaplan and Norton (see figure 1), the BSC comprises of: -Four strategic perspectives: financial, customer, internal business process and learning \& growth ones; Financial: emphasizing shareholder satisfaction, key goals and measures here generally involve (gross and/or net) profitability, return on capital employed, residual income, economic value added, sales growth, market position and share, cash flow. Customer: focusing on "real" customer satisfaction, key goals and indicators here typically stress common customer concerns such as delivery time, quality, service and cost. Internal business: key goals and measures here should highlight critical skills and competencies, processes and technologies that will deliver current and future organizational (customer/financial) success. Learning/growth: underpinning the other three perspectives, key long-term goals and indicators in this regard typically relate to improving flexibility and investing for future development and new opportunities (Atkinson, 2006).

These functions have made the balanced scorecard an effective management system for the implementation of strategy. The balanced scorecard has been applied successfully to private sector companies, non-profit organizations, and government agencies.

Frost (2014) highlighted seven good reasons for the use of Balanced Scorecards. They are;

i. Scorecards Drive Better Performance: The evidence is clear that solid feedback enhances performance at all levels and across all organizational units. When people and groups throughout an enterprise know how they are doing and what needs improving, they do better.

ii. Scorecards Implement Strategy: Scorecards translate your strategy into concrete terms and help you track its implementation. Though scorecards also reflect operational issues, they are developed in a way that specifically directs attention to your strategy and future direction.

iii. Scorecards Help Ensure Right Measures: A group of measures implemented without a well-thought-out performance model in mind or, worse yet, imposed from the outside, seldom bring new focus or drive desired actions. Effective performance scorecards are, by nature, consciously and purposefully constructed. In building one, you develop a logical structure that helps everyone know what should be measured, what belongs on the scorecard and what does not belong.

iv. Scorecards Encourage Balanced Performance: Executing today's work is absolutely crucial, but so is implementing the strategic initiatives that prepare the enterprise for tomorrow. The proper scorecard design keeps the right balance of operational and strategic factors on your radar screen.

v. Scorecards Point out What's Missing: Because your scorecard is designed to offer a comprehensive view of how the enterprise is doing and where it's going, the scorecard will help you see if any key factors are missing the gaps stand out. Those who use unstructured measures without an underlying performance model have no way of knowing what may be missing.

vi. Scorecards Encourage Good Management: As noted earlier, scorecards make it possible to readily monitor all the measures in a complex organization. As a result, reviews are more regular and more thorough. When performance issues stand out on a top-level scorecard, it's possible to "drill down" to layers of data that give further details. The bottom line is that scorecards encourage thorough monitoring and timely corrective actions.

vii. Scorecards Communicate Story: Many individuals and groups take a keen interest in the performance of an enterprise. Strong scorecards help you tell the full story of performance how the complex variables are being balanced and optimized as a group. This allows you to present a compelling picture of performance that is undistorted by focus on an individual issue.

\subsection{Theoretical Framework}

\section{The Stakeholders' Theory}

The basis for stakeholder theory is that companies are so large and their impact on society so pervasive that they should discharge accountability to many more sectors of society than solely their shareholders. Stakeholder theory may be the necessary outcome of agency theory given that there is a business case in considering the needs of stakeholders through improved customer perception, employee motivation, supplier stability, shareholder conscience investment.

The basic proposition of the stakeholder theory is that the firm's success is dependent upon the successful management of all the relationships that a firm has with its stakeholders - a term originally introduced by Stanford Research Institute (SRI) to refer to "those groups without whose support the organization would cease to exist". When viewed as such, the conventional view that the success of the firm is dependent solely upon maximizing shareholders' wealth is not sufficient because the entity is perceived to be a nexus of explicit and implicit contracts between the firm and its various stakeholders. Furthermore, in contrast with the institutional theory where norms are imposed to the firms, the stakeholder theory assumes that firms have the ability to influence not just society in 
general but its various stakeholders in particular. In developing the stakeholder theory, incorporates the stakeholder concept into categories: (1) a business planning and policy model; and (2) a corporate social responsibility model of stakeholder management. Stakeholders in the private universities in accordance with the Balanced Scorecard include the founder, management, students, parent, government, regulatory authority, etc. Therefore, the stakeholders have input in the measurement of performance one way or the other.

\subsection{Empirical Framework}

Various research studies have been conducted on the performance evaluation and balanced scorecards in different sectors including Higher Education Institutions. Relevant empirical studies related to the study are reviewed as follows:

Etim and Agara (2011) examined Balanced Scorecards as the new performance management paradigm for Nigeria firms. The study focused on the implementation of the Balanced Scorecards in both Private and Public Sectors in Nigeria for Performance Management purpose with the adoption of quantitative study using secondary data as methodology used. They found out there are some challenges affecting the introduction and implementation of the Balanced Scorecard in Nigeria. They also discovered that no significant documentation on the translation of Balanced Scorecard. The study exposed other researchers to the significant and benefits of adopting and implementing Balanced Scorecards for effective performance management.

Inaam (2012) worked on the possibility of implementing Balanced Scorecard in Jordanian private universities considering the academic and non-academic staff. In his work, 16 private universities were considered in gathering data through questionnaire in Jordan and the data were measured using descriptive and analytical survey method. He found that the ability to implement the BSC was identified on the basis of the availability of financial resources and essential staff for this implementation (basic requirements to implement the BSC system). The study has exposed other researchers to major resources required to implement BSC in private universities.

Gaafar (2014) conducted studied on using the Balanced Scorecard in private sector organizations: A Case Study of Private Telecommunication Companies in Sudan with longitudinal research design. The study used primary and secondary sources. The Spearman's correlation was used to measure the relation between BS and organization performance. The study revealed that there is strong positive significant relation between BSC and organization performance in telecommunication companies in Sudan. Also, it found that there is strong positive significant relation between financial perspective and organization performance in telecommunication companies in Sudan. The study also show that the BSC is suitable for the telecommunication companies and that they have capacity to implement the technique in evaluating performance.

Amponsah and Onuoha (2013) examined the performance and challenges of private universities in Ghana and Nigeria. The study made use of questionnaire for primary data collection method. Forty Nigerians and Ghanaians studying at the postgraduate level in Babcock University (BU), Nigeria, were sampled. Data obtained were analyzed by descriptive statistics, hierarchical factor analysis and deductive inferences. The study revealed that the private universities were outstanding for their ability to provide uninterrupted academic calendar through the years; for production of the best quality graduates, as well as graduating highly ethical and well-disciplined students. The study further showed that the major problem facing private universities in the two countries is largely financial - high cost of training and development of faculty and staff; lack of well-resourced libraries; inability to retain top quality faculty and staff; inadequate teaching and learning equipment and infrastructure

Nayeri, Mashhadi, and Mohajeri (2008) worked on Universities Strategic Evaluation Using Balanced Scorecard. The study made use of questionnaire and checklist for data gathering to test validation and reliability of the research. It was mentioned that because of its importance, the data for the customer perspective was gathered by a questionnaire from each business schools customers (students). The study which was carried out in 6 Iranian top Business Schools with the checklist and the questionnaire tools focusing on evaluation of universities strategies using Balanced Scorecard (BSC). It was found that universities have gotten a significant advantage in customer perspective which is the most important perspective based on the findings from the study. Also, the study found that implementation of customer and financial perspectives will lead to contribution of other perspective of BSC.

Marete (2015) examined the influence of Balanced Scorecard on organizational performance in Institutions of Higher Learning: A Case Study of University of Nairobi and Centre for Mathematics, Science and Technology Education in Africa. The research design used in this study was case study design where a questionnaire was employed as it enabled the researcher get a detailed analysis of the research problem. From the study, it was found that there is a positive relationship between the balanced scorecard and organizational performance, with performance depending on the four perspectives. Customer perspective was found to be the most popular of the four perspectives in the Higher learning Institutions.

Khorshidi, Mastaneh and Javidkar (2013) studied on the Balanced Scorecard (BSC), as a tool for evaluation of organizational strategies. The current investigation is a type of applied studies in terms of goals, and qualitative in terms data, and librarian type in terms of nature and kind of study. The studied population includes the published scientific essays in leading journals about various perspectives of BSC. With respect to application in conducting 
study, these articles were selected deliberatively and the relevant contents were extracted after study them accurately and based on goals of the current survey. Then, proportional to each of exclusive goals of research, the extracted contents were summarized qualitatively. The study found that BSC created value- added for organizations by providing the relevant and balanced information for managers in brief form, preparation of ground for moving organizations toward learner organizations, and reducing managers' need to types of controlling systems.

Ibrahim and Murtala (2015) investigated the relevance of Balanced Scorecard as a technique for assessing performance in the Nigerian Banking Industry. The study was conducted through primary research using structured questionnaire. The population of the study comprised the entire 21 banks operating in Gombe State, Nigeria. The study was analyzed through descriptive statistics. The study found that there is recognition of the importance of using BSC by the management of Nigerian banks for assessing performance, and the use of the full structure of BSC comprising its four perspectives cannot be seen but only the financial perspective was fully implemented.

Pietrzak, Paliszkiewicz, and Klepacki (2015) examined the application of the Balanced Scorecard (BSC) in the Higher Education Setting of a Polish University. The study was conducted through secondary data by reviewed the records of the University chosen, journals, articles and other periodicals of Polish Universities in Japan. This university was established at the beginning of 19th century and currently could be described at least as a medium size university. It is ranked at 16th position in Polish universities according to the size with the $1.4 \%$ share in the number of students. The study found that application of BSC model has following merit;

- $\quad$ Position in International Rankings

- $\quad$ The system can be adjusted to the changes in environment

- Measurement of intangible assets

Binden, Mziu and Suhaimi (2014) researched on how to employ the Balanced Scorecard (BSC) in measuring performance in Higher Education in Malaysia. The study was conducted through secondary data. Universities in Malaysia were considered to form conclusion. The study found that a proper framework is effectively guided for those academic institutions in Malaysia in order to overcome the BSC implementation and achieve the performance measurement.

Habidin, Yusof, Omar, Syed-Mohamad, and Janudin (2012) worked on a proposed Strategic Balanced Scorecard Model: Strategic Control System and Organizational Performance in Malaysian Automotive Industry. The study made use of secondary data collection which was gotten through review of various related literatures. The study found that Malaysian automotive industry is facing greater challenges due to the general quest for high quality, the requirement and regulation of ASEAN Trade Area (AFTA) and the increasing competition between local car and foreign car manufactures. Therefore, to increase the competitiveness, firms apply many quality program and initiatives such as Balanced Scorecard (BSC).

\subsection{METHODOLOGY}

\subsection{Research Design}

Research survey design was adopted for this study. The research work was carried out at private universities in South-western part of Nigeria. This is because, out of the six geo-political zones in the country with 61 private universities in all as at the time of this study, and the South-west zone has 26 private universities (representing almost $50 \%$ of the total number of private universities in the country). This study was carried out using only primary sources of data collected on the field.

\subsection{Population, Sample Size and Sampling Technique}

The population for this study consist of Nigeria private universities totaling sixty-one (61) in number with focus on their academic and non-academic staff. The sample size for this study was three (3) private universities in the south-western zone. The universities were stratified by religion (Christianity, Islamic and Non-religious based universities) where one was drawn from each stratum. Simple random sample technique was used to choose the sample size from each of the stratum in which three hundred (300) respondents of one hundred (100) from each selected private university were focused.

In order to ensure validity of the questionnaires administered in this research work, the questionnaire was scrutinized by the supervisor to ensure contents validity of the questionnaires. Thereafter, the questionnaire were distributed to the three hundred (300) targeted respondents of one hundred (100) each in the chosen private universities in the south west for their response on the statement raised in the questionnaire. Only two hundred and eighty-eight (288) were received and collected. After collection, the questionnaire were coded and run on the system in order to form good decision and recommendation.

Data collected was decoded, computed and arranged in table and percentage for easy reference. The table method involved the systematic arrangement of facts and figures. In order to determine the effect of independent variables on dependent variable, multiple linear regression models was applied using SPSS. Simple percentages and Chi-square methods were also applied where appropriate. The simple percentages was used for the questions 
in section A and B of the questionnaire to calculation of the numbers of respondents under each category and was presented in a tabular form. The chi-square $(\chi 2)$ was used to test the hypothesis. It was also used to test the validity of the result of the correlation coefficient.

Private Universities' Performance (Revenue level, Profitability level etc.) was considered as the dependent variable in the study. The performance will be evaluated on the basis of financial perspectives (Revenue level, Profitability level etc.) and non-financial perspectives (Students satisfactory grade, Ranking etc.).

The Balanced Scorecard four perspectives (financial, customer, internal process, and learning and growth) were the main independent variables to test the performance of the selected private universities in the zone. Other factor that will be considered in the course of the study to measure performance in the private universities in the South-western zone of the country is religion.

\subsection{Model Specification}

For data analysis, the regression model stated below was adopted for the study:

PUP $=\alpha+\beta 1($ FP) $+\beta 2($ CP $)+\beta 3($ IP $)+\beta 4($ LP $)+\infty$

Where: PUP $=$ Private Universities' Performance (Return on Investment, Profitability level, students' outcome of result etc.)

$$
\begin{array}{ll}
\alpha=\text { Constant factor } \\
\beta 1(\mathrm{FP})= & \text { Financial Perspective Variable } \\
\beta 2(\mathrm{CP})= & \text { Customer Perspective Variable } \\
\beta 3(\mathrm{IP})= & \text { Internal Process Perspective Variable } \\
\beta 4(\mathrm{LP})= & \text { Learning \& Growth Perspective Variable } \\
\infty= & \text { other factor (Religion) }
\end{array}
$$

\subsection{Operationalization of the Variable}

This part of work explained how the variables in the model were measured for decisions and proffer solutions to the research questions in the study. The model;

$$
\text { PUP }=\alpha+\beta 1(\text { FP })+\beta 2(\text { CP })+\beta 3(\text { IP })+\beta 4(\text { LP })+\infty
$$

Where: $\mathrm{PUP}=$ Private Universities' Performance

$$
\alpha=\text { Constant factor }
$$

$\alpha=\mathrm{f}$ (Regulatory framework)

$\beta 1(F P)=\quad$ Financial Perspective Variable

$\boldsymbol{\beta} 1=\mathrm{f}$ (school fee, grants from donors, endowment funds)

$\beta 2(C P)=\quad$ Customer Perspective Variable

$\beta 2=f$ (Numbers of student, Number of academic staff)

$\beta 3($ IP) $=$ Internal Process Perspective Variable

$\boldsymbol{\beta 3}=\mathrm{f}$ (Number of programmes, number of departments, number of faculties)

\section{$\beta 4(L P)=\quad$ Learning \& Growth Perspective Variable}

$\beta 4=f$ (Number of seminars attended, Introduction of professional programmes to students)

$\infty=\quad$ other factor (Religion)

$=\mathrm{f}($ Religion affiliations with educational programme $)$

\subsection{RESULT AND INTERPRETATIONS}

\subsection{Analysis of Data}

In the course of the study, questionnaire were distributed to the three hundred (300) targeted respondents of one hundred (100) each in the chosen private universities in the south west in Nigeria for their response on the statement raised in the questionnaires. Only two hundred and eighty-eight (288) of the questionnaires distributed were returned. This represents ninety-six percent (96\%) completeness rate as a result of proper monitoring and this was considered reasonable for computations and interpretation made in the study. However, the remaining twelve (12) representing four percent $(4 \%)$ were not returned or return unfilled by the respondents.

\subsection{Testing of Hypotheses}

Hypothesis 1 (Ho1): Nigerian private universities do not significantly have capacity of implementing Balanced Scorecard. 
Table 1 Showing Cross Tabulation of Respondents on Hypothesis 1 (Ho1)

\begin{tabular}{|c|c|c|c|c|c|}
\hline S/N & SA (\%) & A (\%) & D (\%) & SD (\%) & $\begin{array}{c}\text { ROW } \\
\text { TOTAL }\end{array}$ \\
\hline i. & 157 & 114 & 9 & 8 & 288 \\
\hline ii. & 133 & 128 & 10 & 17 & 288 \\
\hline iii. & 98 & 154 & 15 & 21 & 288 \\
\hline iv. & 142 & 124 & 8 & 14 & 288 \\
\hline v. & 102 & 109 & 40 & 37 & 288 \\
\hline vi. & 91 & 135 & 42 & 20 & 288 \\
\hline vii. & 117 & 143 & 14 & 14 & 288 \\
\hline viii. & 150 & 108 & 15 & 15 & 288 \\
\hline COLUMN TOTAL & $\mathbf{9 9 0}$ & $\mathbf{1 0 1 5}$ & $\mathbf{1 5 3}$ & $\mathbf{1 4 6}$ & $\mathbf{2 3 0 4}$ \\
\hline
\end{tabular}

\section{Source: Field Survey, 2018}

Table 2 Showing Chi square $(x 2)$ calculated for Hypothesis 1 (Ho1)

\begin{tabular}{|c|c|c|c|c|c|}
\hline Tested Hypothesis & $\begin{array}{c}\text { No of } \\
\text { Observation }\end{array}$ & $\begin{array}{c}\text { Chi square }\left(\boldsymbol{x}^{2}\right) \\
\text { calculated }\end{array}$ & $\begin{array}{c}\text { df (r-1)(c- } \\
\mathbf{1})\end{array}$ & $\begin{array}{c}\text { Critical } \\
\text { Value }\end{array}$ & $\begin{array}{c}\text { Critical } \\
\text { Chi square } \\
\left(\boldsymbol{x}^{2}\right)\end{array}$ \\
\hline $\begin{array}{l}\text { Nigerian private universities do } \\
\text { not significantly have capacity of } \\
\text { implementing Balanced Scorecard. }\end{array}$ & 288 & 1378.03 & 21 & 0.05 & 32.671 \\
\hline
\end{tabular}

\section{Source: Field Survey, 2018}

\section{Interpretation}

From the table above, Chi square $\left(x^{2}\right)$ calculated is 1378.03 as against the Critical Chi square $\left(x^{2}\right)$ of 32.671 at $5 \%$ significant level with 21 degree of freedom. The decision is that whenever the Chi square $\left(x^{2}\right)$ calculated is greater than the Critical Chi square $\left(x^{2}\right)$, the null hypothesis should be rejected and the alternative hypothesis is accepted. Therefore, the null hypothesis of the result should be rejected. This indicates that the null hypothesis stating that Nigerian private universities do not significantly have capacity of implementing Balanced Scorecard is rejected.

Hypothesis 2 (Ho2): Balanced Scorecard perspectives have no significantly effect on the private universities' performance.

Table 3 Showing Cross Tabulation of Respondents on Hypothesis 3 (Ho 3)

\begin{tabular}{|c|c|c|c|c|c|}
\hline S/N & SA (\%) & A (\%) & D (\%) & SD (\%) & ROW TOTAL \\
\hline i. & 177 & 86 & 25 & 0 & 288 \\
\hline ii. & 149 & 95 & 44 & 0 & 288 \\
\hline iii. & 130 & 129 & 29 & 0 & 288 \\
\hline iv. & 124 & 140 & 22 & 2 & 288 \\
\hline v. & 109 & 150 & 27 & 2 & 288 \\
\hline vi. & 152 & 122 & 7 & 7 & 288 \\
\hline vii. & 191 & 75 & 22 & 0 & 288 \\
\hline viii. & 133 & 124 & 27 & 4 & 288 \\
\hline ix & 86 & 175 & 10 & 17 & 288 \\
\hline X & 91 & 185 & 8 & 4 & 288 \\
\hline xi & 166 & 98 & 9 & 15 & 288 \\
\hline xii & 133 & 137 & 16 & 2 & 288 \\
\hline xiii & 112 & 156 & 12 & 8 & 288 \\
\hline xiv & 126 & 149 & 9 & 4 & 288 \\
\hline xv & 137 & 141 & 2 & 8 & 288 \\
\hline Xvi & 147 & 127 & 8 & 6 & 288 \\
\hline Xvii & 77 & 188 & 6 & 17 & 288 \\
\hline xviii & 117 & 150 & 15 & 6 & 288 \\
\hline xix & 131 & 145 & 2 & 6 & 288 \\
\hline xx & 135 & 145 & 2 & 6 & 288 \\
\hline COLUMN TOTAL & $\mathbf{9 9 0}$ & $\mathbf{1 0 1 5}$ & $\mathbf{1 5 3}$ & $\mathbf{1 4 6}$ & $\mathbf{2 3 0 4}$ \\
\hline
\end{tabular}

Source: Field Survey, 2018 
Table 4 Showing Chi square $(x 2)$ calculated for Hypothesis 2 (Ho2)

\begin{tabular}{|c|c|c|c|c|c|}
\hline Tested Hypothesis & $\begin{array}{c}\text { No of } \\
\text { Observation }\end{array}$ & $\begin{array}{c}\text { Chi square }\left(\boldsymbol{x}^{2}\right) \\
\text { calculated }\end{array}$ & $\begin{array}{c}\text { df (r-1)(c- } \\
\mathbf{1})\end{array}$ & $\begin{array}{c}\text { Critical } \\
\text { Value }\end{array}$ & $\begin{array}{c}\text { Critical } \\
\text { Chi square } \\
\left(\boldsymbol{x}^{2}\right)\end{array}$ \\
\hline $\begin{array}{l}\text { Balanced Scorecard perspectives } \\
\text { have no significantly effect on the } \\
\text { private universities' performance }\end{array}$ & 288 & 4110.01 & 57 & 0.05 & 79.082 \\
\hline
\end{tabular}

\section{Source: Field Survey, 2018}

\section{Interpretation}

From the table 4 above, Chi square $\left(x^{2}\right)$ calculated is 4110.01 as against the Critical Chi square $\left(x^{2}\right)$ of 79.082 at $5 \%$ significant level with 57 degree of freedom. The decision is that whenever the Chi square $\left(x^{2}\right)$ calculated is greater than the Critical Chi square $\left(x^{2}\right)$, the null hypothesis should be rejected and the alternative hypothesis is accepted. Therefore, the null hypothesis of the result should be rejected. This implies that the null hypothesis stating that Balanced Scorecard perspectives have no significantly effect on the private universities' performance is rejected.

\subsection{CONCLUSION AND RECOMMENDATION}

\subsection{Conclusion}

After critical analysis of data collected in the course of the study, the result of the finding revealed that implementation of Balanced Scorecard (BSC) is suitable for the private universities and there is capacity in hand of the universities for such implementation but some factors need to be considered as stated below;
i. Willingness of founder(s)/promoter(s) of the private universities
ii. Adequate provision in the universities budget for the implementation of BSC
iii. Proper communication and sensitization of staff on the implementation of BSC
iv. Availability of funds from other sources other than school fees such grant from donors, endowment fund, subventions etc.
v. Adequate availability of teaching aids for learning such as equipped library and information technology tools etc.

\subsection{Recommendations}

In order to have effective implementation of the Balanced Scorecards to evaluate performance in the private universities, the following recommendations from the study will be useful to the stakeholders;

a) Founder(s)/Promoter(s): The founder(s) or promoter(s) of private universities should look into the procedures of implementing BSC for evaluation of performance in their schools and follow same to ensure proper decision making.

b) Regulatory Bodies: The Nigeria University Commission (NUC) as the major regulatory bodies and others should encourage private universities to implement the BSC for performance evaluation of both the students (customer perspective) and staff (internal process perspective)

c) Universities' Administrators: The university administrators need to communicate the BSC process, outcomes, and application with greater clarity to all employees both academic and non-academic staff.

d) Policy Makers: The implementation of BSC as observed in the findings of this study, will help the policy makers within and outside the university environment on how to make decision on performance of the school. Therefore, there is need to study implemented BSC very well before making any policy especially on performance measures.

\section{REFERENCES}

Amponsah E. B. and Onuoha L. N., (2013) The Performance and Challenges of Private Universities in Ghana and Nigeria: International Journal of Business and Social Science Vol. 4 No. 5 Pp.256 - 263

Armstrong M (2001). Human Resource Management Practice, Kogan Page Publishers, 8th edition.

Atkison, A. A., Kaplan, R. S., \& Young, S. M. (2007). Management accounting (5th ed.). New Jersey: Person Prentice Hall.

Binden W., Mziu H., and Suhaimi M. A., (2014) Employing the Balanced Scorecard (BSC) to Measure Performance in Higher Education - Malaysia: International Journal of Information and Communication Technology Research Volume 4 No. 1, ISSN 2223-4985, Pages 38 - 44

Etim, R. S. and Agara, I G, (2011) The Balanced Scorecard: The New Performance Management Paradigm For Nigerian Firms: International Journal of Economic Development Research and Investment Vol. 2 No. 3, Page $64-73$

Gaafar M. A., (2014) Using the Balanced Scorecard in Private Sector Organizations: A Case Study of Private Telecommunication Companies in Sudan: International Business Research; Vol. 7, No. 9; ISSN 1913 - 9004; 
E - ISSN 1913 - 9012 Pages $157-164$

Habidin N. F., Yusof S. M., Omar B., Syed-Mohamad I., and Janudin S. E.,(2012) A Proposed Strategic Balanced Scorecard Model: Strategic Control System and Organizational Performance in Malaysian Automotive Industry: IOSR Journal of Business and Management (IOSRJBM) ISSN: 2278-487X Volume 1, Issue 6 (JulyAug. 2012), PP 39-44 www.iosrjournals.org

Ibrahim M. and Murtala S., (2015) The Relevance of Balanced Scorecard as a Technique for Assessing Performance in the Nigerian Banking Industry: European Journal of Business, Economics and Accountancy Vol. 3, No. 4, ISSN 2056 - 6018, Pages $71-80$

Inaam M. Al-Zwyalif, (2012) The Possibility of Implementing Balanced Scorecard in Jordanian Private Universities: International Business Research; Vol. 5, No. 11, Pages 113 - 120

Kaplan, RS and Norton, DP, (1992) Measures that drive performance, Harvard Business Review, February

Kaplan, RS and Norton, DP, (1996) Using the balanced scorecard as a strategic management system, Harvard Business Review, February

Kaplan, RS and Norton, DP, (2000) Having trouble with your strategy? Then map it, Harvard Business Review, pp. 167-176, September-October

Kaplan, RS and Norton, DP, (2001) The strategy focused organization, Harvard Business School Press, Boston, Massachusetts

Kaplan, RS and Norton, DP, (2003) Strategy maps - converting intangible assets into tangible outcomes, Harvard Business School Press, Boston, Massachusetts

Khorshidi A., Mastaneh Z. and Javidkar M. (2013) The Balanced Scorecard (BSC), as a Tool for Evaluation of Organizational Strategies: Journal of Educational and Management Studies J. Educ. Manage. Stud, Vol. 3 No. 4 ISSN: $2322-4770 \mathrm{Pp}: 428-435$

Marete J. K., (2015) Influence of Balanced Scorecard on Organizational Performance in Institutions of Higher Learning: A Case Study of University of Nairobi and Centre for Mathematics, Science and Technology Education in Africa: European Journal of Business and Management Vol.7, No.20, ISSN 2222 - 1905 (Paper) ISSN 2222 - 2839 (Online) Pages 106 - 116

Nayeri M. D., Mashhadi M. M., and Mohajeri K., (2008) Universities Strategic Evaluation Using Balanced Scorecard: International Journal of Social, Behavioral, Educational, Economic, Business and Industrial Engineering Vol. 2, No. 1, Pages 25 - 30

Niven, P.R. and Man, S.V., (2011). Introduction to the Balanced Scorecard. Balanced Scorecard: Step-by-Step for Government and Nonprofit Agencies (pp. 4 - 8)

Punniyamoorthy, M., \& Murali, R. (2008). Balanced score for the balanced scorecard: A benchmarking tool. Benchmarking: An International Journal, 15(4), 420-443.

Pietrzak M., Paliszkiewicz J., and Klepacki B., (2015) The Application of the Balanced Scorecard (BSC) in the Higher Education Setting of a Polish University: Online Journal of Applied Knowledge Management: A Publication of the International Institute for Applied Knowledge Management Vol. 3, Issue 1, Pp. 151 - 164 